\title{
Методика лапароскопічної апендектомії в ургентному лікуванні гострого апендициту
}

\begin{abstract}
Мета работи: вивчення методики ургентної лапароскопічної апендектомії з використанням біполярної коагуляції на рівні районної лікарні. Робота базується на результатах хірургічного лікування 87 хворих, оперованих ургентно з приводу гострого апендициту в хірургічному відділенні Ужгородської районної лікарні.
\end{abstract}

Ключові слова: гострий апендицит, ургентна лапароскопічна апендектомія, біполярна коагуляція

Гострий апендицит (ГА) - найбільш поширене хірургічне захворювання органів черевної порожнини і стабільно займає перше місце за частотою госпіталізації та виконаними операціями серед гострих хірургічних захворювань живота [12]. Серед усіх невідкладних операцій, які виконуються на органах черевної порожнини при “гострому животі”, частка апендектомій складає 20-50 \% [3].

Захворюваність на ГА в економічно розвинених країнах коливається від 4-6 \% до 12-23 \% або 4-5 випадків на 1000 чоловік на рік [7].

Захворюваність на ГА в Україні становила у 2000 році 20,4 на 10000 населення [6].

Близько 80 \% апендектомій в нашій країні виконується в районних лікарнях.

Післяопераційна летальність від гострого апендициту становить 0,1 - 0,4 \% [8]. Діагностичні помилки при цьому захворюванні досягають 10 $-15 \%$ [5].

Відомо, що класична апендектомія має недоліки, до яких відносять травматичність доступу, неможливість повноцінної ревізії та санації черевної порожнини, ризик розвитку спайкового процесу з залученням маткових труб у жінок з наступним безпліддям, інфікування післяопераційної рани, висока вірогідність утворення післяопераційних гриж, відносно тривалий період непрацездатності [4]. У безпосередньому післяопераційному періоді у частини пацієнтів виникають такі загальнохірургічні ускладнення, як інфільтрат, нагноєння рани, кровотеча з брижі відростка, перитоніт, абсцес черевної порожнини, кишкові нориці, динамічна і рання спайкова кишкова непрохідність тощо $[1,2]$.

За останнє десятиріччя широкого застосування набули лапароскопічні методики апендектомії [9]. Економічна ефективність, відмінні косметичні результати, нетривалий больовий період після лапароскопічної апендектомії зумовлює все більшу ії розповсюдженість. Застосування лапароскопії як методу оперативного лікування, особливо у паці- єнтів з ожирінням, достовірно є більш ефективним втручанням порівнянні з відкритою операцією [10]. Встановлено, що летальність після лапароскопічної апендектомії нижча, ніж після відкритої операції [8]. На думку деяких дослідників, лапароскопічна апендектомія $є$ операцією вибору при гострому апендициті у хворих всіх вікових груп [11].

Для пацієнтів важливим є швидке одужання, раннє виписування зі стаціонару, мінімальний косметичний дефект шкіри в зоні операційного доступу, відновлення якості життя та працездатності.

Таким чином, вибір способу операції - класична за Волковичем-Дьяконовим чи лапароскопічна апендектомї на сьогодні є актуальною проблемою в екстренній абдомінальній хірургії.

Мета роботи: вивчення методики ургентної лапароскопічної апендектомії з використанням біполярної коагуляції на рівні районної лікарні.

В роботі проаналізовано результати лікування 87 хворих, оперованих ургентно з приводу гострого апендициту. За гендерними особливостями 36 пацієнтів (41 \%) - жінки, 51 пацієнт (59 \%) - чоловіки. Середній вік - 27,6 року. У всіх хворих (100 \% випадків) встановлено діагноз гострого апендициту.

У ході дослідження хворі були поділені на 2 групи: I група, 48 (55 \%) пацієнтів, яким виконано ургентну лапароскопічну апендектомію; II група - 39 (45 \%) пацієнтів, яким було проведено класичну апендектомію за Волковичем-Дьяконовим.

Всім хворим (100 \%) операційне втручання виконували під загальним знеболенням (внутрішньовенний наркоз).

Пацієнтам першої групи виконували лапароскопічну апендектомію за методикою з 3-х троакарних доступів: в зоні пупка (троакар 10 мм), між лонним симфізом та пупком (троакар 5 мм) та в лівій (троакар 10 мм) здухвинній ділянці (розрізи шкіри завдовжки приблизно 15 мм, 7 мм та 15 мм відповідно). Після встановлення лапароскопа через порт над пупком виконували ревізію черевної 
порожнини, візуалізували анатомічні особливості та патологічні зміни червоподібного відростка, наявність та характер ексудату. Через порт у лівій здухвинній ділянці встановлювали перехідник на 5 мм та вводили робочий інструмент - біполярний коагуляційний дисектор. Через порт між симфізом та пупком затискачем Бебкока захоплювали апендикс та проводили тракцію останнього в краніо-латеральному напрямку. При цьому брижа червоподібного відростка натягувалась, що дозволяло проводити скелетизацію та мобілізацію останнього. Мобілізацію починали від верхівки апендикса шляхом біполярної коагуляції брижі з подальшим пересіченням останньої одразу біля стінки паростка. Така методика проводилась на всьому протязі брижі відростка аж до основи. У жодному випадку не спостерігали кровотечі з судин брижі апендикса. Після повної мобілізації до купола сліпої кишки на основу паростка почергово накладали та затягували 3 петлі Редера з інтервалом 3-5 мм. Паросток відсікали між накладеними дистальною та середньою петлями і видаляли через порт у лівій здухвинній ділянці. Куксу паростка обробляли марлевим тампоном, змоченим в антисептик (“Бетадин”, “Бетайод”, “Кутасепт”). Ексудат з черевної порожнини евакуйовували електровідсмоктувачем; дренували порожнину малого таза трубчатим дренажем, введеним через порт між симфізом та пупком. Після видалення троакарних портів рани зашивали 1-2 окремими швами або внутрішньо шкірним швом.

Пацієнтам другої групи виконували апендектомію за Волковичем-Дьяконовим з розрізу шкіри через точку МакБурнея з лігуванням судин брижі паростка шляхом прошивання та перев'язки, відсіканням апендикса та зануренням кукси останнього в кисетний та Z-подібний шви. При наявності ексудату в порожнині малої миски черевну порожнину санували та дренували через окремий розріз (5-10 мм) у правій здухвинній ділянці.

Ведення хворих обох груп у післяопераційному періоді не мало суттєвих відмінностей. Хворим призначали антибактеріальні, знеболювальні та протизапальні препарати. Серед анальгетиків перевагу віддавали наркотичним - Трамадолу 5 \%-2,0 двічі на добу внутрішньом'язово в перші 12 годин після операції та ненаркотичному Медролгіну 30 мг двічі на добу внутрішньом'язово перші 2-3 доби післяопераційного періоду. Перев'язки здійснювались за стандартними методиками.

Пацієнтів I групи вертикалізовували через 2-6 годин після операції; дренажну трубку видаляли на 1-3 добу після операції; виписували із стаціонару на 2-5 добу. У всіх пацієнтів (100 \%) І групи спостерігали загоєння післяопераційних ран пер- винним натягом. Жодних ускладнень в ранньому та пізньому післяопераційному періодах не було. Працездатність відновлена на 7-10 день після операції.

Зі слів 100 \% пацієнтів, післяопераційні рубці їх не турбують та абсолютно влаштовують.

Серед ускладнень у хворих II групи слід виділити сероми в зоні післяопераційної рани у 5 хворих (5,7 \%), виявлені на 5-7 добу післяопераційного періоду та ліквідовані шляхом часткового розведення країв рани між швами і евакуації серозного вмісту, подовженням антибіотикота протизапальної терапій. У 1 хворого (1,1%) II групи спостерігалось нагноєння післяопераційної рани на 6 добу після операції з формуванням абсцесу в підшкірній жировій клітковині (хворий 3 гострим гангренозно-перфоративним апендицитом), що потребувало зняття швів з рани, розкриття та санації гнійника, подовження антибіотикотерапії та привело до загоєння рани вторинним натягом, формування гіпертрофічного шкірного рубця та подовження терміну перебування хворого в стаціонарі до 16 днів. У 1 хворої $(1,1 \%)$ II групи на 12 добу після операції виявлено абсцес порожнини малого таза (хвора з гострим гангренозно-перфоративним апендицитом). Абсцес розкрито, сановано та дреновано шляхом проведення хворій релапаратомії через апендектомний доступ. Загалом хвора провела в стаціонарі 18 днів.

Працездатність пацієнтів II групи була відновлена на 14-30 день після операції.

Летальних випадків у жодній з досліджуваних груп не було.

Ліжко-день становив у I групі - від 2 до 5 днів (у більшості випадків - 4 дні), у II групі - від 5 до 18 днів (у більшості випадків - 7 днів).

Висновки. 1. Лапароскопічну апендектомію вважаємо методом вибору при ургентному лікуванні гострого апендициту.

2. Застосування біполярної куагуляції та лапароскопічного біполярного дисектора дозволяють швидко та якісно скелетизувати та відділити апендикс від власної брижі.

3. Методика лапароскопічної апендектомії зменшує відсоток можливих ускладнень в післяопераційному періоді, призводить до мінімальних косметичних та естетичних дефектів шкіри.

4. Ургентна лапароскопічна апендектомія забезпечує ранню активацію пацієнтів після операції, пришвидшує відновлення працездатності та значно скорочує час перебування хворого в стаціонарі.

5. Використання препарату Медролгін 30 мг у післяопераційному періоді забезпечує адекватне знеболення, що допомагає ранній активації оперованих пацієнтів. 


\section{ПОВІДОМЛЕННЯ}

\section{СПИСОК ЛІТЕРАТУРИ}

1. Кригер А. Г. Лапароскопическое лечение острого аппендицита / А. Г. Кригер, А. М. Череватко, Э. Р. Фаллер // Эндоскопическая хирургия. - 1995. - № 2-3. - С. 34-36.

2. Кошелев П. И. Видеолапароскопически ассистированные аппендэктомии / П. И. Кошелев, Г. Н. Карпухин, И. А. Рягузов // Эндоскопическая хирургия. - 2005. - № 1. - С. 65.

3. Современные подходы к диагностике и лечению острого аппендицита / В. Д. Левитский, А. А. Гуляев, П. А. Ярцев, М. Л. Рогаль // Эндоскопическая хирургия. - 2011. - № 1. C. 55-61.

4. Орехов Г. И. Место эндовидеохирургической технологии в лечении больных острым аппендицитом / Г. И. Орехов // Эндоскопическая хирургия. - 2009. - № 3. - С. 35-38.

5. Ротков И. Л. Диагностические и тактические ошибки при остром аппендиците / И. Л. Ротков. - М. : Медицина, 1998. -208 c.

6. Совцов С. А. Является ли острый аппендицит фазным заболеванием? / С. А. Совцов, В. Ю. Подшивалов // Скорая медицинская помощь. - 2004. - № 3. - С. 54-57.

7. Качество жизни больных после лапароскопической аппенд- эктомии / Ю. М. Стойко, А. А. Новик, А. Л. Левчук [и др.] // Эндоскопическая хирургия. - 2010. - № 1. - С. 3-7.

8. Risk of complications and 30-day mortality after laparoscopic and open appendectomy in a Danish region, 1998-2007; a population-based study of 18426 patients / S. Bregendahl, M. Nørgaard, S. Laurberg, P. Jepsen // Pol. Przegl. Chir. - 2013. - No. 7. - P. 395-400.

9. Cash C. L. Improvements in laparoscopic treatment for complicated appendicitis / C. Cash, R. Frazee // J. Laparoendosc. Adv. Surg. Tech. A. - 2012. - Vol. 22, No. 6. - P. 581-583.

10. Costa-Navarro D. Laparoscopic appendectomy: quality care and costeffectiveness for today's economy / D. Costa-Navarro, M. Jiménez-Fuertes, A. Illán-Riquelme // World J. Emerg. Surg. - 2013. - Vol. 8, No. 1. - P. 45.

11. Outcomes and cost analysis of laparoscopic versus open appendectomy for treatment of acute appendicitis: 4-years experience in a district hospital / V. Minutolo, A. Licciardello, B. Di Stefano [et al.] // BMC Surg. - 2014. - Vol. 14, No. 1. - P. 14.

12. Ryan W. L. Appendicitis: Symptoms, diagnosis and treatments / W. L. Ryan. - New-York: Elsivier. - 2010. - 380p.

\section{REFERENCES}

1. Kriger, A.G., Cherevatko, A.M., \& Faller, E.R. (1995). Laparoskopicheskoye lecheniye ostrogo apenditsita [Laparoscopic treatment of acute appendicitis]. Endoskopicheskaya khirurgiyaEndoscopic Surgery, 2-3, 34-36 [in Russian].

2. Koshelev, P.I., Karpukhin, G.I., \& Ryaguzov, I.A.(2005). (2005). Videolaparoscopicheski assistirovanye appendektomii [Video laparoscopically assisted appendectomy]. Endoskopicheskaya khirurgiya - Endoscopic Surgery, 1, 65 [in Russian].

3. Levitskiy, V.D., Gulyaev, A.A., Yartsev, P.A., \& Rogal, M.L. (2011). Sovremennye podkhody k diagnostike i lecheniyu ostrogo apenditsita [Modern approaches to the diagnosis and treatment of acute appendicitis]. Endoskopicheskaya khirurgiya - Endoscopic Surgery, 1, 55-61 [in Russian].

4. Orekhov, G.I. (2009). Mesto endovideokhirurgicheskoy tekhnologii v lechenii bolnykh ostrym appenditsitom [The place of endovideo surgical technology in the treatment of patients with acute appendicitis]. Endoskopicheskaya khirurgiya - Endoscopic Surgery, 3, 35-38 [in Russian].

5. Rotkov, I.L. (1998). Diagnosticheskiye i takticheskiye oshybki pri ostrom appenditsite [Diagnostic and tactical errors in acute appendicitis]. Moscow: Meditsina [in Russian].

6. Sovtsov, S.A., \& Podshyvalov, V.Yu. (2004). Yavlyaetsya li ostryy appenditsit faznym zabolevaniem [Is acute appendicitis a phase disease?]. Skoraya meditsinskaya pomoshch - Emergency,

\section{3, 54-57 [in Russian].}

7. Stoyko, Yu.M., Novik, A.A., \& Levchuk, A.L. (2010). Kachestvo zhizni bolnykh posle laparoskopicheskoy appendektomii [Quality of life of patients after laparoscopic appendectomy]. Endoskopicheskaya khirurgiya - Endoscopic Surgery, 1, 3-7 [in Russian].

8. Bregendahl, S., Nørgaard, M., Laurberg, S., \& Jepsen, P. (2013). Risk of complications and 30-day mortality after laparoscopic and open appendectomy in a Danish region, 1998-2007; a populationbased study of 18426 patients. Pol. Przegl. Chir., 7, 395-400.

9. Cash, C.L., \& Frazee, R. (2012). Improvements in laparoscopic treatment for complicated appendicitis. J. Laparoendosc. Adv. Surg. Tech A, 22 (6), 581-583.

10. Costa-Navarro, D., Jiménez-Fuertes, M., Illán-Riquelme, A. (2013). Laparoscopic appendectomy: quality care and costeffectiveness for today's economy. World J. Emerg. Surg., $8(1), 45$.

11. Minutolo, V., Licciardello, A., Di Stefano, B., Arena, M., Arena, G., \& Antonacci, V. (2014). Outcomes and cost analysis of laparoscopic versus open appendectomy for treatment of acute appendicitis: 4-years experience in a district hospital. BMC Surg., $14(1), 14$

12. Ryan, W.L. (2010). Appendicitis: Symptoms, diagnosis and treatments. New-York: Elsivier. 
V. M. VORONYCH, M. V. VORONYCH, N. M. LASKINA, V. YU. BARA

Public Non-commertial Institution "Uzhhorod District Clinical Hospital"

\section{METHODS OF LAPAROSCOPIC APPENDECTOMY IN URGENT TREATMENT OF ACUTE APPENDICITIS}

The aim of the work: to substantiate the laparoscopic appendectomy in the urgent treatment for patients with acute appendicitis. The work is based on the results of surgical treatment of 87 patients operated urgently for acute appendicitis eat the Surgical Department of Uzhhorod District Hospital.

Key words: acute appendicitis; urgent laparoscopic appendectomy; bipolar coagulation.

В. М. ВОРОНИЧ, М. В. ВОРОНИЧ, Н. М. ЛАСКИНА, В. Ю. БАРА

Коммунальное некомерческое предприятие "Ужгородская районная клиническая больница"

\section{МЕТОДИКА ЛАПАРОСКОПИЧЕСКОЙ АППЕНДЭКТОМИИ В УРГЕНТНОМ ЛЕЧЕНИИ ОСТРОГО АППЕНДЕЦИТА}

Цель работы: изучение методики ургентной лапароскопической аппендэктомии по использованию биполярной коагуляции на уровне районной больницы. Работа базируется на результатах хирургического лечения 87 больных, оперированных ургентно по поводу острого аппендицита в хирургическом отделении Ужгородской районной больницы.

Ключевые слова: острый аппендицит; ургентная лапароскопическая аппендэктомия; биполярная коагуляция. 